九州大学学術情報リポジトリ

Kyushu University Institutional Repository

\title{
Development and Utilization of the Wholesale Price Information System for Agricultural, Livestock and Fishery Products in Korea
}

Lee, Kang Oh

Foodsafety team, Korea Information Center for Agriculture, Forestry and Fisheries

Song, Min Young

Foodsafety team, Korea Information Center for Agriculture, Forestry and Fisheries

Nakaji, Ke i

Laboratory of Agricultural Ecology, Division of Agronomy \& Environmental Sciences, Department of Agro-environmental Sciences, Faculty of Agriculture, Kyushu University

https://doi.org/10.5109/18850

出版情報 : 九州大学大学院農学研究院紀要. 55 (2)，pp. 333-340，2010-10-29. 九州大学大学院農学研究 院

バージョン:

権利関係 : 


\title{
Development and Utilization of the Wholesale Price Information System for Agricultural, Livestock and Fishery Products in Korea
}

\author{
Kang Oh LEE ${ }^{1 *}$, Min Young SONG ${ }^{1}$ and Kei NAKAJI ${ }^{2}$ \\ ${ }^{1}$ Foodsafety team, Korea Information Center for Agriculture, Forestry and Fisheries, Korea \\ ${ }^{2}$ Laboratory of Agricultural Ecology, Division of Agronomy \& Environmental Sciences, \\ Department of Agro-environmental Sciences, Faculty of Agriculture, \\ Kyushu University, Fukuoka 811-2307, Japan \\ (Received June 30, 2010 and accepted July 9, 2010)
}

\begin{abstract}
The Korea Information Center for Agriculture, Forestry and Fisheries developed the Wholesale Price Information System for agricultural, livestock and fishery products. The System provides auctioned price information in real-time for 33 public wholesale markets and three legal and general wholesale markets in Korea. Moreover, the system provides settlement price after collecting, processing and analyzing wholesale and market price of agricultural products. A survey showed that $72.2 \%$ of the users have used the information system at least more the once a week, and $88.8 \%$ users have spent more than five minutes or each connection. Most users (76.7\%) evaluated the information system is helping in to increase income.
\end{abstract}

\section{INTRODUCTION}

The developed according to development of Information Technology (IT) has dramatically expanded the internet. Users can now access the internet for collecting and sharing huge amounts of information anytime and anywhere. In addition, the internet worldwide has developed numerous types of business (e.g., the distribution \& marketing industry and advertisement industry, etc.). Even technology development through the internet is actively applied in the agricultural sector.

Actively utilizing new IT technology in the agricultural field is an important in coping with the market opening of agricultural products. Rapidly changing international situations shch as the Uruguay Round, FTA and WTO, etc. have urged farmers and people related to agricultural industry to acquire the most recent and advanced information for improving agricultural productivity and enhancing competitiveness (J. H. Lee, et al., 2001, W. B. Kim. et al., 2001). Developing the Wholesale Price Information System also helps farmers gain higher benefits by providing information about the timing and methods for the shipment of agricultural products after a harvest.

Through exclusively internet-based system in Korea, the Korea Information Center for Agriculture, Forestry and Fisheries (KICAFF), the Agricultural and Fishery Marketing Corporation and the General Forest Products Distribution Center are providing market price information for agricultural, livestock and fishery products. In addition, the Korea Rural Economic Institute issues a monthly bulletin on the internet that includes agricultural observations on major items (MIFAFF, 2009-a).

${ }^{1}$ Foodsafety team, Korea Information Center for Agriculture, Forestry and Fisheries, Korea

${ }^{2}$ Laboratory of Agricultural Ecology, Division of Agronomy \& Environmental Sciences, Department of Agro-environmental Sciences, Faculty of Agriculture, Kyushu University, Fukuoka 811-2307, Japan

* Corresponding author (E-mail: leeko2@affis.net)
Especially, the Wholesale Price Information System of agricultural, livestock and fishery products by the KICAFF has been operated to support the decisionmaking for the shipment such as an optimal timing and market decision in the shipment stage of agricultural, livestock and fishery products. The operation of the system started with major five items in vegetables. The Wholesale Price Information System is provides the shipment price and distribution information of products in the wholesale market about almost all items being currently traded in the 33 public wholesale markets. The farmers and distributors can reasonably decide the timing of shipping for agricultural, livestock and fishery products through the wholesale price information system and can increase the actual income of farmers (M. Y. Song, et al., 2006).

The present thesis aims to describe the development of the Wholesale Price Information System products being operated by the KICAFF and to describe the content and utilization of the wholesale price information in real-time being serviced to the distributors involved in the field.

\section{MATERIALS AND METHODS}

\section{Status of Agricultural Wholesale Market in Korea}

The agricultural wholesale market in Korea is largely divided into 1) the public wholesale market, 2) the legal and general wholesale market and 3) the public wholesale market based on the investment subject.

A total of 50 agricultural wholesale markets, composed of 33 public wholesale markets, 14 general legal wholesale markets and 3 public wholesale markets have been respectively operated by the Government, The number of wholesale corporations is 121 , and the current workers are 3,133 (Table 1).

The trading volume in 2008 of the public wholesale market, general legal wholesale market and public wholesale market was 6,604,448 tons, 330,690 tons and 22,071 tons, respectively. Thus, the total trading volume was 7,257,209 tons (9721.6 billion won) (Table. 2). 
Table 1. Status by wholesale market of Korea (MIFAFF, 2009-b)

(Unit : locations, persons)

\begin{tabular}{lrrrr}
\hline \multicolumn{1}{c}{ Division } & Total & $\begin{array}{c}\text { Public wholesale } \\
\text { market }\end{array}$ & $\begin{array}{c}\text { General } \\
\text { corporation } \\
\text { wholesale market }\end{array}$ & $\begin{array}{c}\text { Private wholesale } \\
\text { market }\end{array}$ \\
\hline Market Quantity & 50 & 33 & 14 & 3 \\
Wholesale corporation quantity & 121 & 104 & 14 & 3 \\
Market corporation quantity & 55 & 55 & 559 & - \\
Wholesale corporation employees & 3,133 & 2,551 & 577 & 23 \\
Moderate bond & 8,429 & 7,829 & 150 & 23 \\
Trade participant & 575 & 396 & & 29 \\
\hline
\end{tabular}

Table 2. Trade performance by wholesale market (MIFAFF, 2009-b)

(Unit : ton, one hundred million)

\begin{tabular}{|c|c|c|c|c|c|c|c|c|}
\hline \multirow{3}{*}{ Division } & \multicolumn{4}{|c|}{2007} & \multicolumn{4}{|c|}{2008} \\
\hline & \multicolumn{2}{|c|}{$\begin{array}{c}\text { The amount of } \\
\text { materials }\end{array}$} & \multicolumn{2}{|c|}{$\begin{array}{c}\text { The amount of } \\
\text { money }\end{array}$} & \multicolumn{2}{|c|}{$\begin{array}{c}\text { The amount of } \\
\text { materials }\end{array}$} & \multicolumn{2}{|c|}{$\begin{array}{c}\text { The amount of } \\
\text { materials }\end{array}$} \\
\hline & & $\%$ & & $\%$ & & $\%$ & & $\%$ \\
\hline Total & $6,993,325$ & 100 & 93,230 & 100 & $7,257,209$ & 100 & 97,216 & 100 \\
\hline Public wholesale market & $6,653,382$ & 95.2 & 84,279 & 90.4 & $6,904,448$ & 95.1 & 86,702 & 88.8 \\
\hline General corporation wholesale market & 323,326 & 4.6 & 8,793 & 9.4 & 330,690 & 4.6 & 10,275 & 10.5 \\
\hline Private wholesale market & 16,617 & 0.2 & 158 & 0.2 & 22,071 & 0.3 & 239 & 0.7 \\
\hline
\end{tabular}

\section{Development of Wholesale Price Information System of Agricultural, Livestock and Fishery Products}

The KICAFF provides the wholesale price information of agricultural, livestock and fishery products to help farmers or distributors decide an optimal shipment period and market decision in a shipment stage of agricultural, livestock and fishery products. A shipment support system was developed for agricultural products especially for five major items of vegetables of which price was heavily fluctuated as a stimulation project of distribution reform measures in 1998 to increase actual income of farmhouses and distribution efficiency.

The KICAFF is currently servicing auctioned settlement information and real-time auction information of 33 public wholesale markets across the nation after verifying its effectiveness of provision of internet information since its system development, provided comprehensive analysis information on major 67 items. The Wholesale Price Information System provides the real-time distribution price information of agricultural products through collection, process and analysis of distribution information such as survey price and information of agricultural, livestock and fishery products-related institutions. The system also provides the market situation for the distribution of agricultural products including non-major items by expert groups forecast information, information of housewife survey and a weekly trend of agricultural products, and so on.

The subject of using the Wholesale Price Information System is mainly farmers, and people having interest in the price and volume information of agricultural prod- ucts, such as general consumers, distribution workers of agricultural products, agricultural policy's decision maker, related researchers and college students of agricultural colleges, etc. The system has also provided various service methods considering convenience of users such as wired or wireless internet service, SMS (Sort Message Service), RSS (Really Simple Syndication) service, information sharing through FTP (File Transfer Protocol), fax and order information.

\section{Configuration of Auctioned Information Transmission System of Wholesale Market of Price Information of Agricultural, Livestock and Fishery Products}

The Wholesale Price Information System provides the information of the public wholesale market's payment and the real-time auction price by e-auction after collection and process of data.

The computer system collects the payment price of daily auction information according to auction execution from 107 wholesale corporations of 33 public wholesale markets and 3 general legal wholesale market in Korea, and service settlement price information after processing data collected through the wired (WEB, RSS) and wireless (PDA, SMS) Internet.

Also, the Wholesale Price Information System of agricultural, livestock and fishery collects/processes the real-time auction price by e-auction from 33 public wholesale markets ( 79 wholesale corporations) and 1 general legal wholesale market (one wholesale corporation) in the nation. The system is operated in real time, and it is provided to related institutions after being dispersedly 
processed. The farmers and distribution information workers can utilize distribution information such as auction price information of the wholesale market anytime through the wired and wireless Internet and can ship agricultural products in optimal price conditions.

Figure 1 showed configuration of the auction infor-

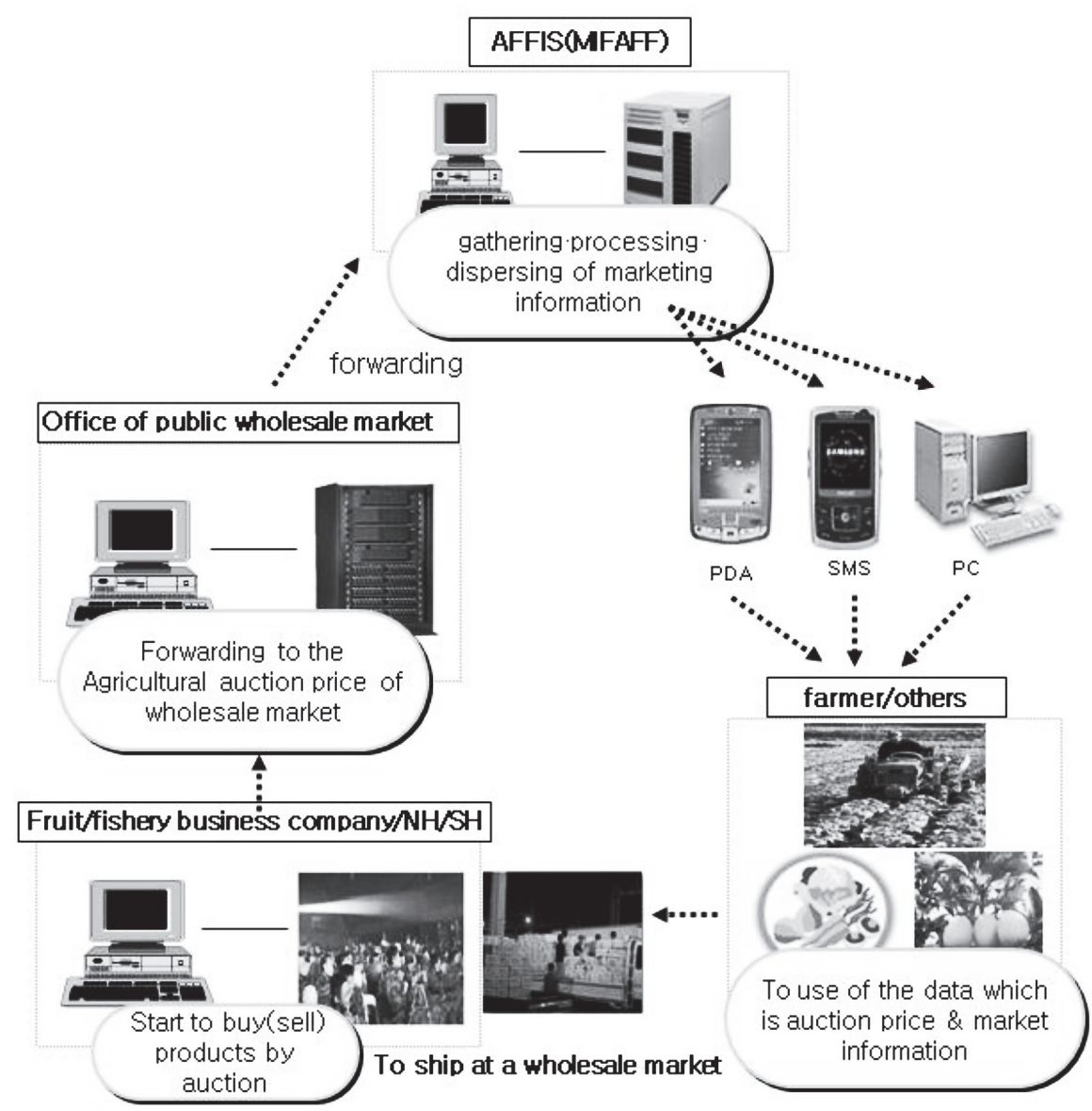

Fig. 1. Configuration of auctioned price transmission system of public wholesale market.

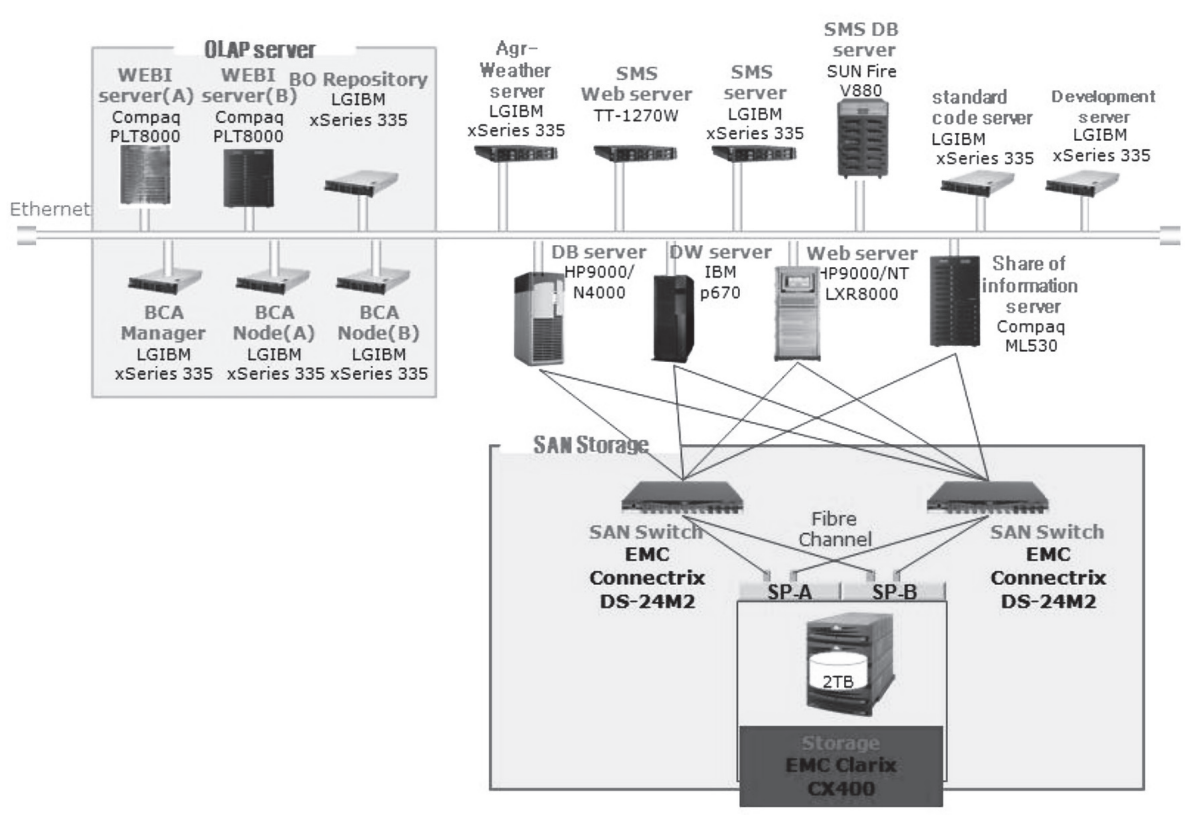

Fig. 2. Hardware configuration of the Wholesale Price Information System of agricultural, livestock and fishery products. 
mation transmission system of the Wholesale Price Information System of agricultural, livestock and fishery products. The system obtains the auction price from public wholesale markets. Therefore, farmers and people in the distribution fields can use the auction information.

\section{Hardware Configuration and Major Server Specifications of Price $\bullet$ Distribution Information System of Agricultural, Livestock and Fishery Products}

The configuration of hardware of the Wholesale Price Information System consists of Chulha web server, Data Base (DB) server, Data Warehouse (DW) server, On-Line Analytical Processing (OLAP) server, Information sharing server, standard code management server, agricultural weather server, SMS web server, SMS DB server and development server, and so on. The system was organically designed and configured to provide final analysis information to users by extracting and processing necessary information through OLAP technology at different databases stored at the DW server. A SAN Storage was established for continuous increase of data and stable data accumulation (Fig. 2).

The KICAFF constructed and has been operating an optimal hardware system in order to provide the price information of safe agricultural, livestock and fishery products.

\section{RESULTS AND DISCUSSION}

\section{Collection and Analysis System Map of Source Data of the Wholesale Price Information System}

of Agricultural, Livestock and Fishery Products

The collection process of source data of the Wholesale Price Information System showed that the Management Corporation/Office collected the transaction information of 33 public wholesale markets across the nation. The transaction information and e-auction information is transmitted to the shipment support system online in real time.

The transaction information of the producing district's joint market of each region and wholesale transaction information of Comprehensive Agricultural Cooperative Distribution Center are collected from the National Agricultural Cooperatives Federation. The retail transaction information of large distributers and consumer market is collected through the Agricultural and Fishery Marketing Corporation, honorary housewife reporters for price evaluation and consumer organizations. It is totaled at the distribution Wholesale Price Information System. The livestock auction information is collected from the transaction information of the Animal Products Grading Service (APGS), and the flowers transaction information is collected from the flowers joint market of Yanjae-dong and then analyzed (Fig. 3)

The source data collected from each wholesale market and related institutions are stored in a DB server and DW server through processing and verification of data quality. The information is provided to users (farmers, Agriculture-related institutions and general users, etc.) in real time through a shipment supporting web server after passing through the OLAP server by the wired and wireless media.

The entire data processing from all the sources is automated, and the manpower consumption was mini-

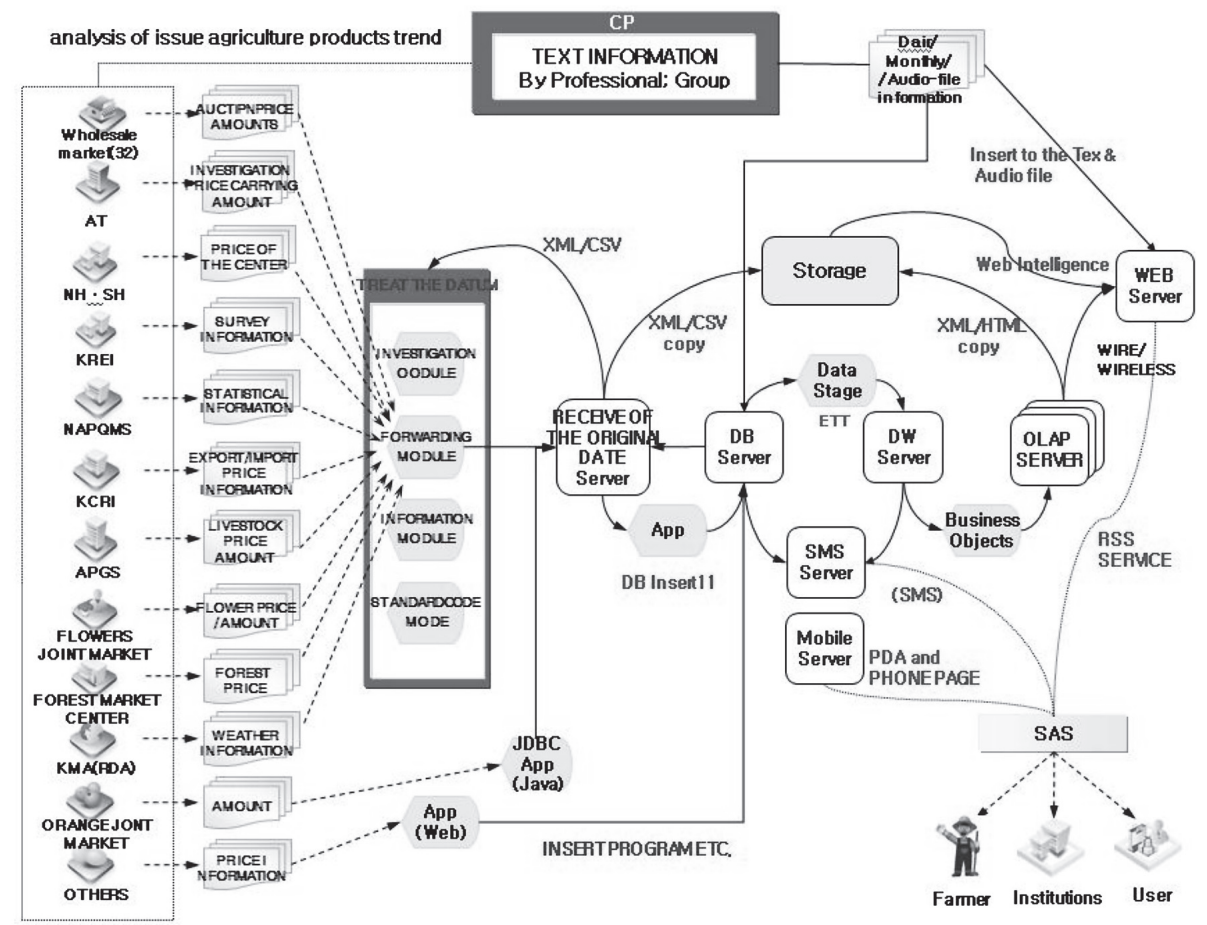

Fig. 3. Collection and analytical processing configuration of source data of the Wholesale Price Information System of agricultural, livestock and fishery products. 
mized by enhancing efficiency of data processing. Therefore the objectiveness of data was improved.

First, the source data transmitted from the national wholesale market is constructed as DB of the DW server and stored after going through data processing and error verification is performed at the IT room of the KICAFF.

The first step of source data processing is checking errors and abnormality of the source data transmitted to a reception server of source data of AFFIS. When the source data is normally distributed the information is incorporated into a DB server. Then the summary DB is stored in a DW server after going through Extraction Transformation Transportation (ETT) work. Finally the data are provided to users by generating a screen for service (Html document) at the OLAP server, so that users can quickly search the desired information by using Business Objects (BO).

\section{Collecting and Sharing the System of Price Survey Information of Agricultural, Livestock and Fishery Products}

The information of wholesale Price Information Sharing System being operated at the KICAFF is largely divided into 2 kinds.

One is sharing the wholesale price information provided from the shipping support system constructed after collecting the auction and surveyed price, etc. The information is collected from 33 public wholesale markets and 3 general legal wholesale markets across the nation. The other one is information sharing of the surveyed distribution price integrated by collecting the surveyed price distribution of Agricultural, Livestock and Fishery Products surveyed from each agriculture-related institutions and processing/analyzing the source data.

The KICAFF is operating the system to lead related institutions to utilize various and much Agricultural information through the information sharing system collected price distribution information of Agricultural, Livestock and Fishery Products.

The survey institution and data content for information sharing and utilization showed that the information sharing system collects various information agricultural officials' branch office of each region, producing district of Agricultural Cooperative, the price of agricultural products at a joint market, the price information of fishery products of the consignment market of Fisheries
Cooperatives, the price and carrying-in volume of the wholesale and retail market of Agricultural and Fishery Marketing Corporation, surveyed price of the Garak market of Seoul Agricultural \& Marine Products Corporation, and distribution information of agricultural products' source data of related institutions and organizations.

The source data collected in the information sharing system of the KICAFF are distributed and dispatched to agriculture-related institutions needing agricultural information after computational data processing of the source data.

For activation of information sharing on price/distribution information, the KICAFF developed Open API service which can be applied to the operating system and to the development environment and can link with the outside efficiently and comprehensively. This Open API service has been effectively solving convenient utilization the linkage of information for information demanders.

\section{Operation and Information Registration of Expert Group by item}

The local distribution experts of each wholesale market consisted of an expert group by item. The expert group provides market information, forecast information, a prompt report on distribution, etc. through text and video, and provides distribution information 5 6 times per month according to each item.

The local information-providing experts consisted of superior information providers such as reporters of professional newspaper, distributer of producing district, auctioneer, wholesaler, other distribution workers, distribution organizations of environment-friendly agricultural products and consumer organizations, etc. At present, 11 institutions CP and 77 individual CP (2008) are participating as a professional information provider.

The information provision status according to a type being provided showed that there were a total of 3,509 cases registered (Table. 3). Specifically there are 2001 cases of market information, 312 cases of forecast information, 97 cases of the price of environment-friendly agricultural products, 49 cases of consumer's price, 954 cases of housewife survey price, 55 cases of the trend of Chinese agricultural products, and 41 cases of a weekly trend of agricultural products.

The local expert provides the live distribution price

Table 3. Registration status of monthly market/forecast information/video distribution information (Dec., 2008)

\begin{tabular}{|c|c|c|c|c|c|}
\hline Division & 2004 & 2005 & 2006 & 2007 & 2008 \\
\hline Quotes information & 4,008 & 5,320 & 6,354 & 2,988 & 2,001 \\
\hline View information & 609 & 787 & 1,076 & 419 & 312 \\
\hline Green information & - & - & 18 & 142 & 97 \\
\hline Consumer information & - & - & 8 & 7 & 49 \\
\hline Survey information housewives & - & - & 223 & 807 & 954 \\
\hline Trends of weekly agricultural product & - & 50 & 49 & 50 & 41 \\
\hline Videos distribution information & 910 & 1,028 & 822 & 170 & - \\
\hline Total & 5,527 & 7,185 & 8,550 & 4,607 & 3,509 \\
\hline
\end{tabular}


of agricultural and livestock products, so farmers or distributors can get more profit.

\section{Main screen Explanation of the Wholesale Price Information System of Agricultural, Livestock and Fishery Products}

The Wholesale Price Information System can be used through the webpage (http://chulha.okdap.net).

Figure 4 is an example showing a main screen of the agricultural products' shipment support system. Users can obtain the price information such as real-time auction report, auction price information, surveyed price information, consumer price information, the price information of environment-friendly agricultural products and the price information of overseas agricultural products (Table 4).

In addition, users can check wholesale price information such as market information, forecast information, a trend of environment-friendly agricultural products, a trend of overseas agricultural products, and a trend of weekly agricultural products. Users can also check statistical information such as daily/monthly volume information by wholesale market, and analysis information such as wholesale price of agricultural products by region, price comparison by wholesale market, and monthly mean survey price, etc. The information provision institutions and data processing capacity of the market price information system of agricultural, livestock and fishery prod-

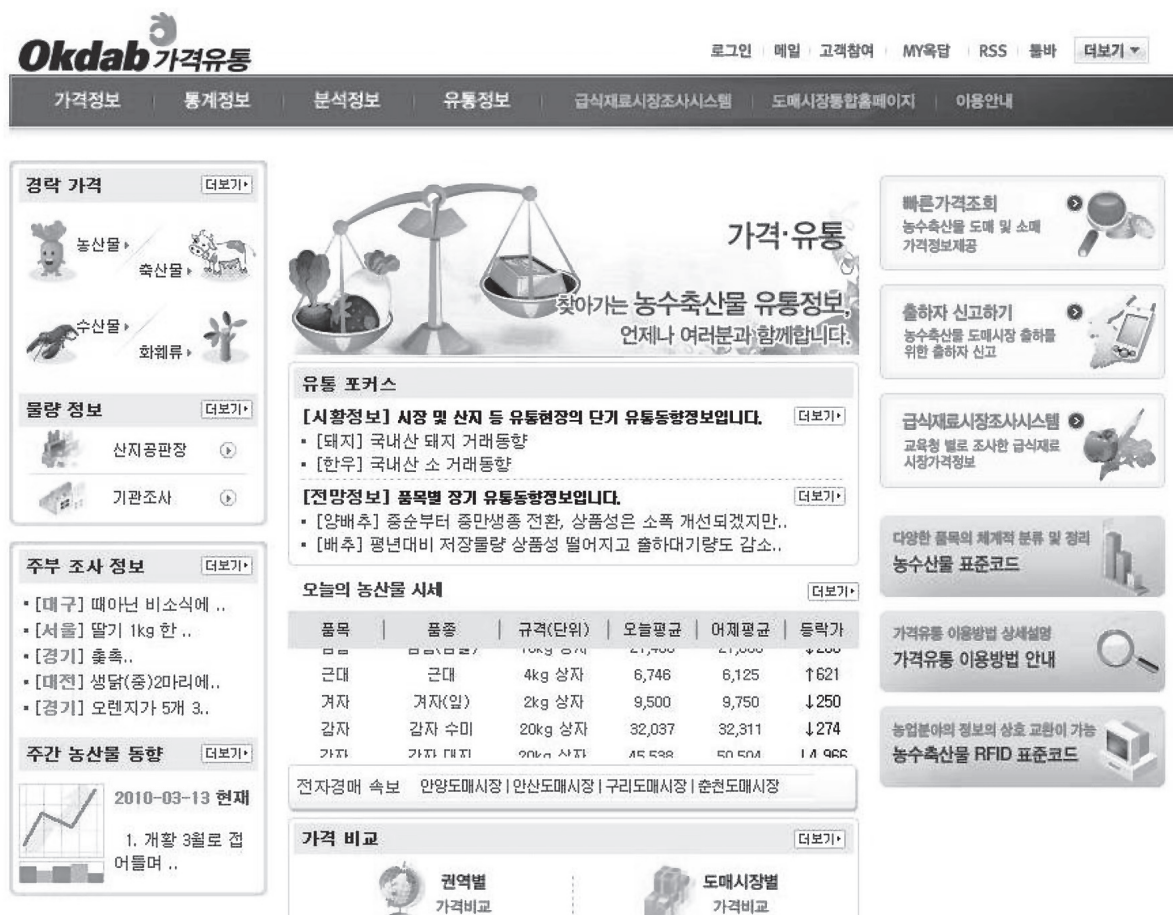

Fig. 4. Example of initial main screen of the Wholesale Price Information System of agricultural, livestock and fishery products.

Table 4. Contents type of the Wholesale Price Information System of Agricultural, Livestock and Fishery Products

\begin{tabular}{|c|c|c|}
\hline & Contents & Type \\
\hline Auction price & $\begin{array}{l}\text { Real-time auction price, agricultural auction price, livestock raising auction } \\
\text { price, flowering plants auction price, fisheries products auction price, districts } \\
\text { price, center of general market price }\end{array}$ & Data \\
\hline $\begin{array}{l}\text { Investigation } \\
\text { price }\end{array}$ & $\begin{array}{l}\text { Garak/Gangse market price, agriculture-fisheries-livestock price, average price, } \\
\text { rice price of the whole country, import-agriculture auction price, chicken/egg } \\
\text { price, forestry price, consumer of meat price }\end{array}$ & Data \\
\hline Carrying amount & $\begin{array}{l}\text { Carrying amount of the wholesale market, carrying amount of the organ } \\
\text { investigation, carrying amount of the general center, carrying amount of the } \\
\text { organ investigation }\end{array}$ & Data \\
\hline Market price & $\begin{array}{l}\text { Dairy price information, prospective price information, audio-file price } \\
\text { information, consumer price information, weekly price information }\end{array}$ & $\begin{array}{l}\text { Data, Voice, } \\
\text { Text }\end{array}$ \\
\hline $\begin{array}{l}\text { Statistics } \\
\text { information }\end{array}$ & $\begin{array}{l}\text { Export-import agricultural price information, livestock/orange/meat/ rice/etc } \\
\text { statistics }\end{array}$ & Data \\
\hline
\end{tabular}


Table 5. Main DB construction and processing status of the Wholesale Price Information System of agricultural, livestock and fishery products(Dec., 2009)

\begin{tabular}{|c|c|c|}
\hline DB contents & providers & DB capacity \\
\hline agriculture-fisheries-livestock price, average price & NH(gardening/livestock), aT, $\mathrm{SH}$ & $600 \mathrm{~kb} /$ day \\
\hline auction price of 3public wholesale market & 33public wholesale market & $15 \mathrm{Mb} /$ day \\
\hline auction price of general legal wholesale market & 3general legal wholesale market & 20kb/day \\
\hline Garak/Gangse market price & aT & $200 \mathrm{~Kb} /$ day \\
\hline Real-time auction price & 34 wholesale market & $5 \mathrm{Mb} /$ day \\
\hline carrying amount of the organ investigation & $\mathrm{NH}$ & $20 \mathrm{~kb} / \mathrm{day}$ \\
\hline fisheries market price & $\mathrm{SH}$ & $4 \mathrm{Mb} /$ day \\
\hline fisheries products auction price & $\mathrm{SH}$ & $60 \mathrm{~kb} /$ day \\
\hline livestock raising auction price & APGS & 8Kb/day \\
\hline flowering plants auction price & aT flows market & $11 \mathrm{~Kb} /$ day \\
\hline chicken/egg price & association & $10 \mathrm{~Kb} /$ day \\
\hline Dairy price information & KICAFF & Everyday \\
\hline Export-import statistics & MIFAFF & $1 \mathrm{Mb} /$ month \\
\hline Export-import agricultural price information & KCRI & $600 \mathrm{~Kb} /$ day \\
\hline consumer of meat price & MIFAFF & $75 \mathrm{~Kb} /$ quarter \\
\hline livestock statistics & MIFAFF & $20 \mathrm{~Kb} / \mathrm{month}$ \\
\hline Carrying amount of the wholesale market & 33public wholesale market & $20 \mathrm{~Kb} /$ day \\
\hline Carrying amount of the Garak market & $\mathrm{aT}$ & $2 \mathrm{~kb} /$ day \\
\hline Dairy price information & MIFAFF & 20kb/week \\
\hline rice price of the whole country & NH & $20 \mathrm{~kb} /$ week \\
\hline weekly price information & KICAFF & Each week \\
\hline
\end{tabular}

ucts were specifically shown in (Table. 5).

\section{Status of the Wholesale Price Information System of Agricultural, Livestock and Fishery Products}

The Wholesale Price Information System provides information with various methods. First, the information provision through wired and wireless homepage services is servicing a general content of the Wholesale Price Information System as well as the price and distribution trend and weather information, etc. through text of a mobile phone. The system is also executing RSS service based on XML about market information, forecast information, video distribution information. The information system is executing data information sharing between related institutions through Open API and FTP.

Members of all sites such as the Wholesale Price Information System being operated by the KICAFF, AFFIS portal and farmers education can use other sites simultaneously through integrated certification (SSO).

Accordingly, although it was difficult to separate the members in only the Wholesale Price Information System, the number of integrated members of the AFFIS system were 264,371 people as of December 2008, and the number of one-day visitor was surveyed as 19,000 . The page view of the shipment support system showed that the daily page view was surveyed as 95,019.17 (2008).

A survey was conducted to identify the current uses of the Wholesale Price Information System from November 10 to December 5, 2007.

The 372 people (farmer:183, non-farmer: 189) were participated in the survey across the nation. The structured questionnaire was distributed to online and offline users (KICAFF, 2007).
The results showed that the frequency of connection was $26.1 \%$ of "every day" and $25.7 \%$ of " $3 \sim 4$ times a week" and thus, the ratio of users who have connected minimum more than once a week was $72.2 \%$.

The average length of time for using information at one-time connection was mostly "more than 10 minutes" (56.4\%) and "less than 5 10 minutes" (32.4\%). More than $75 \%$ of responders said that the obtained information was very helpful (Fig. 5).

The most frequently used information use was in order of "auction price of wholesale market" $45.5 \%$, "realtime auction's prompt report" $17.4 \%$ and "market and forecast information" $17.4 \%$. The major items of using were fruits (38.8\%), vegetables (34.9\%), livestock $(12.1 \%)$ and flowers (8.6\%). Most users (76.7\%) have gotten benefits in increasing income by using the Information system (Fig. 6).

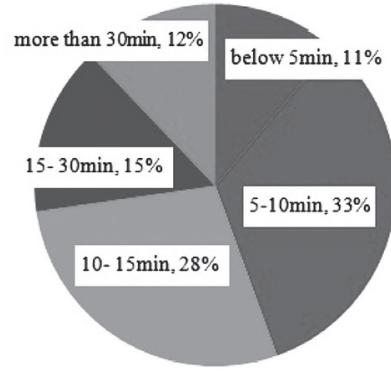

(a) connection rate a week

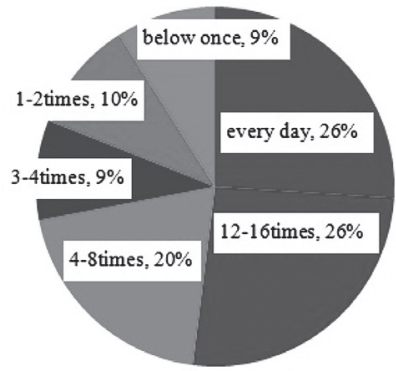

(b)using time of one-connection a month
Fig. 5. Status and connection time of Wholesale Price Information System. 


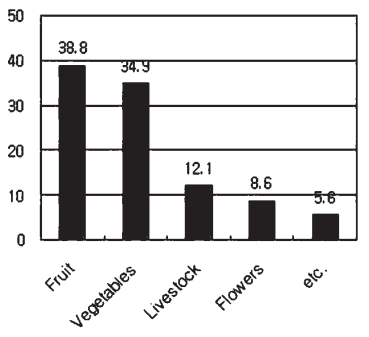

(a) Major using Item

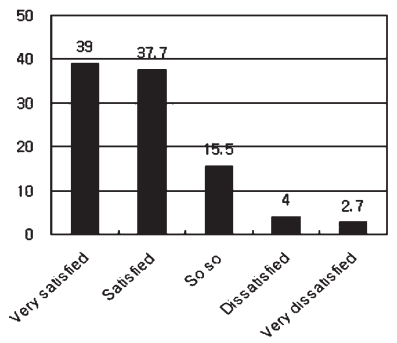

(b) Income Expansion Effects
Fig. 6. Major using item information and income expansion effects of the Wholesale Price Information System.

Lastly, the additional information that users want to receive in the future appeared as "production technology information by item" 33.5\%, "crops information by chief producing district" $26.8 \%$, and "price forecast information" 25.9\%. It was recognized through the survey that the role and support of "expert consulting" $53.4 \%$ is the most necessary.

\section{CONCLUSION AND SUMMARY}

The Wholesale Price Information System developed by the KICAFF has been operated to provide comprehensive and systematic distribution information of agricultural, livestock and fishery products.

The characteristics of the Wholesale Price Information System are as follows. First, the system provides auction information by item and real-time auction information of 33 public wholesale markets in the nation. And it provides real-time price distribution information professionally and comprehensively analyzed on 67 items with much volume. Second, the price information is provided depending on distribution stages such as surveyed price information, producing district, wholesale and consumers on overall items of agricultural, livestock and fishery products of agriculture-related institutions. Third, the source data transmitted from agriculture-related institutions and organizations was processed while its overall processes on collection, processing and distribution are automated. Fourth, the standard codes of agricultural, livestock and fishery products are operated and managed after the classification code system is standardized according to the item, a kind, grade, quality, and packing status.

Furthermore, the Wholesale Price Information System was developed to provide information for users in various routes such as the wired or wireless Internet, SMS, PDA, FAX, RSS, and so on. The unilateral letters of the Wholesale Price Information System were 95,019 people and responders of more than $75 \%$ of responders were very satisfied in information use.

The expected information services in the future were "production technology information by item (33.5\%)", "crops information by chief producing district (26.8\%)", and "price forecast information (25.9\%)". The priority should be the function of "expert consulting (53.4\%)".

The Wholesale Price Information System is planning to develop a forecast information system in the future through the shipment factor analysis of agricultural, livestock and fishery products and to continuously develop the user-customized price/distribution system through the advancement of analysis systems by being deviated from a simple market price information provider for agricultural products.

\section{REFERENCES}

J. H. Lee, et al. 2001 Development of agricultural marketing information system. CREI report

W. B. Kim, et al. 2001 The buildup of electronic control system for agriculture products arrival and shipment in wholesale markets. ARPC research report

M. Y. Song, K. O. Lee, Y. J. Kim, B. J. Kim and M. H. Lee 2006 Management and development of agriculture shipment aid system to support the price and distribution information in Korea. ISMAB2006 Seoul in Korea, pp. 158-165

MIFAFF 2009-a Investigate the product distribution information, skills enrichment. MIFAFF

MIFAFF 2009-b 2008, Statistical yearbook of wholesale market. MIFAFF

KICAFF 2007 AFFIS price-distribution information user needs analysis and performance analysis report. KICAFF

http://chulha.affis.net 2010

http://market.affis.net 2010

http://www.nonghyup.com 2010

http://www.krei.re.kr 2010 